Canadian University Music Review

Canadian University Music Review

Revue de musique des universités canadiennes

\title{
Synchronization by the Grace of God? The Film/Music Collaboration of Jean Cocteau and Georges Auric
}

\section{James Deaville et Simon Wood}

Volume 22, numéro 1, 2001

Jean Cocteau: Evangelist of the Avant-garde Jean Cocteau : évangéliste de l'avant-garde

URI : https://id.erudit.org/iderudit/1014501ar DOI : https://doi.org/10.7202/1014501ar

\section{Aller au sommaire du numéro}

\section{Éditeur(s)}

Canadian University Music Society / Société de musique des universités canadiennes

\section{ISSN}

0710-0353 (imprimé)

2291-2436 (numérique)

Découvrir la revue

Citer cet article

Deaville, J. \& Wood, S. (2001). Synchronization by the Grace of God? The Film/Music Collaboration of Jean Cocteau and Georges Auric. Canadian University Music Review / Revue de musique des universités canadiennes, 22(1), 105-126. https://doi.org/10.7202/1014501ar

\section{Résumé de l'article}

La place qu'occupe la musique dans les films de Jean Cocteau n'a jamais fait l'objet d'une étude approfondie. En effet, le parti pris ouvert de Cocteau contre la synchronisation fait penser qu'il accordait peu d'importance aux liens entre l'image, la parole et la musique, d'autant plus qu'il confiait celle-ci à son fidèle ami Georges Auric. Toutefois, un examen attentif des partitions d'Auric en regard des films correspondants permet de révéler qu'il existe, entre musique et film, une relation beaucoup plus étroite que ce que les spécialistes avaient cru jusqu'ici (ou que Cocteau admettait). Une analyse des éléments musicaux et filmiques des productions Le Sang d'un poète (1932), La Belle et la Bête (1946) et Orphée (1949) suggère une approche riche et complexe, quoique conventionnelle, de la composition de musique de film, à la fois par Auric et Cocteau.
All Rights Reserved @ Canadian University Music Society / Société de musique des universités canadiennes, 2002
Ce document est protégé par la loi sur le droit d'auteur. L'utilisation des services d'Érudit (y compris la reproduction) est assujettie à sa politique d'utilisation que vous pouvez consulter en ligne.

https://apropos.erudit.org/fr/usagers/politique-dutilisation/ 


\title{
SYNCHRONIZATION BY THE GRACE OF GOD? THE FILM/MUSIC COLLABORATION OF JEAN COCTEAU AND GEORGES AURIC
}

\author{
James Deaville and Simon Wood
}

... one must let the film act like Auric's noble accompanying music. Music gives nameless nourishment to our emotions and memories ...

The most important musical collaboration of Jean Cocteau's film career was that which he shared with composer Georges Auric (1899-1983). Auric contributed original scores for four of the six films directed by Cocteau between the years 1930 and 1960, including: Le Sang d'un poète (1930), La Belle et la Bête (1945), Les Parents terribles (1948), and Orphée (1949). Auric was also called upon to contribute music for several films in which Cocteau was involved as a writer, such as L'Éternel Retour and Ruy Blas (1947). His music is a constant and powerful presence in Cocteau's films; however, a review of the literature on this collaboration constantly reaffirms, unquestioned, Cocteau's claim that he randomly "reordered" Auric's music in an effort to avoid any musical and narrative synchronization, save that which happens "by the grace of God." Does the evidence of the films themselves support this claim, or do they reveal a higher level of intent on the part of Auric and Cocteau than the latter would care to admit? Following a brief historical introduction, we will compare the literature surrounding the collaboration between Cocteau and Auric with the music of the films, in an investigation that will bring this accepted view into question.

Georges Auric was born on 15 February 1899 in Lodève, France. Following early musical studies at the Montpellier Conservatory, he attended the Paris Conservatory and the Schola Cantorum. In his early twenties, he found himself in the company of Arthur Honegger, Darius Milhaud, Francis Poulenc, Louis Durey and Germaine Tailleferre, an informal collection of Parisian composers whom the critic Henri Collet called Les Six Français-an epithet that they did not reject, even though the members of this group had little in common with each other. Interested in the promotion of French over foreign (in particular German) art, Cocteau anointed himself spokesman for the group, promoting them in his pamphlet-format manifesto entitled Le Coq et l'Arlequin.

1 Jean Cocteau speaking at an early showing of Le Sang d'un poète in January 1932. In Jean Cocteau, Two Screenplays, trans. Carol Martin-Sperry (New York: Orion Press, 1968), 66.

2Ned Rorem, "Cocteau and Music," in Jean Cocteau and the French Scene, ed. Dore Ashton (New York: Abbeville Press, 1984), 169. 
After Durey, Auric was the least well-known of Les Six, possibly because he seemed most comfortable working in the genre of the film score (he wrote music for 40 French, 40 American and 15 British films), which undoubtedly contributed to his marginalization and relative obscurity up to the present. ${ }^{3}$ Despite the fact that his association with Cocteau is mainly responsible for Auric's reputation, he was a highly successful composer of film scores in his own right, working with several well-known British and American directors, such as William Wyler (Roman Holiday, 1953), John Huston (Moulin Rouge, 1952), Otto Preminger (Bonjour Tristesse, 1958) and Terence Young (The Poppy Is Also a Flower, 1966). It is interesting to note that while André Boucourechliev's entry "Auric" in the New Grove Dictionary of Music and Musicians gives a complete list of his ballets and orchestral works, only eleven of his almost 100 film scores receive mention, the majority of which are his collaborations with Cocteau. ${ }^{4}$ Absent from the list are scores for films such as The Lavender Hill Mob (1951) and The Innocents (1961). ${ }^{5}$ His first work in film (Cocteau's Le Sang d'un poète, 1930) followed naturally from a series of theater scores and ballets composed during the 1920s, including the ballets Les Fâcheux from 1923 or Pastorale from 1925. Indeed, Auric is remembered as a "discreet" and "visual" composer, well suited to work in a visual medium.

In Paris of the early twentieth century, this tendency towards the visual is not unique to Auric, however. On the one hand, the French were the first to take the composition of film scores seriously; Camille Saint-Saëns is generally recognized as being the first composer of an original score for a film (for $L$ 'Assassinat du duc de Guise of 1908). On the other, the French predilection for ballet, and more specifically, the enthusiasm for the ballets of Igor Stravinsky (whose revolutionary works both Cocteau and Auric revered) and for the ballet troupe of Sergei Diaghilev, influenced many a composer in Paris during the war years and the 1920s. Auric's pre-filmic work included the ballets Les Fâcheux (1924), Les Matelots (1925), La Pastorale (1926) and Les Enchantements d'Alcine (1929)—all written for productions by Diaghilev. Furthermore, two of the other composers from Les Six-Darius Milhaud and Arthur Honegger-wrote film scores, Milhaud collaborating with Marcel l'Herbier on L'Inhumaine (1923) and, after the loosening of Les Six, scoring the experimental film Petite Lili (1929), and Honegger worked with director Abel Gance on silent films La Roue (1924) and Napoléon (1927). Thus, film music was already a significant factor within the circle of musicians known as Les Six before Auric began his film collaboration with Cocteau. In fact, when the young Miklos Rozsa met Honegger in Paris, in 1932, the latter identified his occupation not as composer, but as "writing film music." 6

3Film music and its composers have traditionally been neglected by music scholarship. The standard bibliographic literature about music tends to perpetuate this bias against film music, by ignoring those aspects of a composer's career.

4 Andre Boucourechliev, "Auric, Georges," The New Grove Dictionary of Music and Musicians, ed. Stanley Sadie, vol. 1 (London: Macmillan, 1980), 704.

5 See Steven Smith, Film Composers Guide (Beverly Hills: Lone Eagle, 1990) for a complete filmography.

6Roy M. Pendergast, Film Music: A Neglected Art, $2^{\text {nd }}$ ed. (New York: W. W. Norton \& Company, 1992), 68 . 
Though the precise date of their first encounter is unclear, Auric and Cocteau knew each other by 1915 or 1916 , thus prior to the period of Les Six. ${ }^{7}$ Their correspondence establishes a relationship of mutual admiration by 1918 . This relationship was by no means static, evolving over the course of time. Despite their admiration for each other's abilities, the ten-year age difference led to Cocteau taking on the role of a mentor, if not a father, towards the younger musical prodigy. Auric looked up to Cocteau, but more importantly for their film collaboration, Cocteau exhibited an ongoing confidence in the musician, for he invited Auric to participate in all of the cinematic projects for which Cocteau served as writer-director, from Le Sang d'un poète through Testament d'Orphée of 1960. Cocteau also helped secure Auric's musical collaboration on films for which he was script writer but not director: L'Éternel Retour (1943) and Ruy Blas (1947). Beyond the screen, the friendship generated projects such as Auric's songs Huit poèmes de Jean Cocteau (1917), the Les Six collaborative ballet Les Mariés de la tour Eiffel to a scenario by Cocteau (1921) and Auric's ballet Phèdre to a scenario by Cocteau (1950). ${ }^{8}$ That the relationship extended beyond the artistic to the realm of the personal is readily evident from the letters between them, which reveal Cocteau above all sharing his deepest feelings and fears. Certainly Auric is the composer of Les Six with whom Cocteau was the closest. However, there were also moments of tension within the relationship, such as that occasioned by Auric's contributions in 1919 to the journal Littérature, edited by Cocteau's arch-enemies André Breton and Philippe Soupault. ${ }^{9}$ Also, from Cocteau's side, Auric's role in his films tends to be downplayed for specific reasons that will become clear during the course of this analysis.

\section{The Films of Cocteau ANd Auric}

Discussions of film music are often hampered by the entrenched, yet errant presupposition that the quality of the music is dependent on its ability to "stand" on its own. Well-intending colleagues comment that the music may work well in the film, but it lacks any real structure when heard in isolation. Only recently has music criticism acknowledged that film music functions-indeed, is designed to function - as a part of a larger system of signification. ${ }^{10}$ To consider film music without some reference to film as a whole is as if we were to discuss a painter's selections of colours without reference to the subject matter of the painting. If film music "falls apart" once removed from the visual narrative, it is because the visual narrative itself is what structures the music. This leads to a second related dilemma for anyone who would attempt a discussion of film

7Pierre Caizergues, Correspondance: Georges Auric - Jean Cocteau (Montpellier: Centre d'étude du XX ${ }^{e}$ siècle, Université Paul-Valéry, 1999), 5 ("Préface"). Our thanks to Pauline Pocknell of McMaster University's Department of French for her assistance with the translation of these letters.

8 Caizergues, Correspondance: Georges Auric - Jean Cocteau, 8.

9See Georges Auric, Quand j'étais là (Paris: Bernard Grasset, 1979), 103-6.

10 See Simon Wood, "Scoring the Body: Psychoanalysis, Image schemata, and the Syntax of the Narrative Film Score" (Master's Thesis, McMaster University, 1999), 70-77. 
music: to understand Auric's work, we must first consider how Cocteau's own views and experiences shaped the production of his films.

Three of Cocteau's films offer a particularly vivid focus for this understanding: La Belle et la Bête, Cocteau's now-legendary retelling of the classic fairy-tale; and Le Sang d'un poète and Orphée, which-together with Le Testament d'Orphée - form a cycle of works known as Cocteau's "films of orphic identity." 11 For Cocteau, the power of the poet's muse is derived from the notion of death and rebirth: in order for the poet to create, he must first experience a metaphorical death. As such, the figures of the Poet, Orpheus, and, to a lesser extent, the Beast, are powerful manifestations of the artist's self-vision. A central concept required for the understanding of Cocteau's filmic vision is that of the "zone." The zone is that through which the poet must pass in order for him to experience the rebirth required for the creation of the true poet. In all three films the central character must pass through this transitional realm to fulfill his role as a manifestation of the poetic muse within the real world. This zone or transitional realm could be entered through a mirror, a symbol with fetish-like recurrence in Cocteau's films. For Cocteau, the mirror represented a doorway through which one may pass into another world. It is the intersection of life and death: that which shows us the constant progression of age. The mirror is the portal through which death passes-the entrance to the zone. This concept will play an important musical role in all three films under scrutiny here.

\section{Le Sang d'un poète}

In a comment representative of the esteem in which the first Cocteau/Auric film collaboration is held, Ned Rorem describes Le Sang d'un poète as "the greatest wedding on film of film and music." 12 While possibly overstating the case, the film is an intriguing intersection of Cocteau's poetic vision, the French musical avant-garde, and the emerging art of the motion picture. Of particular appeal to musicians and music critics is the technique employed to score the film. Rorem writes that:

Auric himself once told me that in scoring Le Sang d'un poète he produced what is commonly known as love music for love scenes, game music for game scenes, funeral music for funeral scenes. Cocteau had the bright idea of replacing the love music with the funeral, game music with love, funeral with game. And it worked. ${ }^{13}$

This approach to the scoring of the film has appealed to music critics with their disdain for the conventional (read: Hollywood) approach in which the music is added following the film's completion. The score is viewed as a servant of the film, forced to fit the constraints of narrative and technology. Also, it conforms to the modernist ideology that Cocteau wished to establish

11 Arthur B. Evans, Jean Cocteau and His Films of Orphic Identity (London: Associated University Presses, 1977).

12Rorem, "Cocteau and Music," 169.

13Ibid. 
for himself. Rorem's anecdote indicates that, like the critics, Cocteau gave voice to a lively disdain for the conventions. Yet, Auric did attempt to score the film in something of a conventional manner, producing cues which were then reorganized (by Auric and Cocteau or by Cocteau alone?) into the final cut of the film. Cocteau himself describes how he:

shifted and reversed the order of the music in every single sequence. Not only did the contrast heighten the relief of the images, but I even found at times that the "displaced" music adhered too closely to the gestures, and seemed to have been written on purpose. ${ }^{14}$

Cocteau seems to be suggesting that the reordered cues created a synthesis of film and music which was consistent with his artistic vision, generating moments of synchronization which he found desirable. Typical of his tendency to exaggerate, Cocteau even states that some of the reordered music worked too well, although he cites no examples of where this occurred.

Le Sang d'un poète was produced only two years after the advent of sound. It is not until the period of the late 1930s (the advent of the Hollywood "Classical Studio" period) that the conventions of sound film scoring were codified in the works of composers such as Max Steiner and Erich Wolfgang Korngold. However, there were clearly established guidelines for the scoring of silent films, and it is here that we may find the conventions upon which Auric based his "love music for love scenes." More importantly, we may also assume (as Cocteau himself suggests) that the final decisions about the music to accompany specific scenes were deliberate. As we will see, the cues are selected carefully to fit particular moods as well as to fit the timing of a particular scene. Some cues are reused at various points in the film and, at times, have been edited in order to fit the scene. Although Cocteau may have claimed that synchronization of music and image must not occur save by the grace of God, it would seem that the ostensibly modernist auteur was not above giving God a helping hand.

Le Sang d'un poete is not a narrative film in the conventional sense of the term. It is instead a series of four "fantastic" episodes, framed by the demolition of a large chimney. The opening sequence of the film shows the chimney beginning to topple; however, before the fall is complete, the scene changes to reveal the room of the "poet," the starting point for the fantastic journey. The film concludes with the final half of the chimney's demise, which suggests that all that transpires within the film does so in the blink of an eye.

The scoring of Le Sang d'un poète is reminiscent of a pit orchestra (single winds, percussion and dominated by the piano). The resultant "cabaret" timbre is hardly surprising, given the music-hall flavor of the times that was already much in evidence in Auric's theatre and ballet music. Notwithstanding the technical limitations of the time, which would have made the superposition of music and dialogue difficult, Auric and Cocteau place the music in what might be described as an episodic fashion, around moments of dialogue.

14 André Fraigneau, Cocteau on the Film: Conversations with Jean Cocteau, trans. Vera Traill (New York: Dover Publications, Inc., 1972), 73. 
Auric composed a series of themes for the film, some of which are confined to only one scene, or group of scenes based in one location. Other themes reappear in two or more episodes of the film, which suggests that a hierarchy of themes exist, with the most "important" able to transcend the restraints of a particular scene or episode. Following a flourish in the brass, the opening credits are accompanied by a theme in a quick $6 / 8$ time (example 1). Auric juxtaposes the keys of $\mathrm{D}$ major and $\mathrm{D}$ minor, whose conflicting thirds lend the motive a jazz-like quality. This jazz influence is further reinforced by the highly syncopated accompaniment, the incorporation of a mixolydian seventh degree ( $\mathrm{C}$ natural in the key of $\mathrm{D}$ major), and a phrase derived from a $\mathrm{D}$ major pentatonic scale. The theme is almost neurotic in quality, moving quickly from phrase to phrase in a pastiche of musical motives, scored in a variety of quick changes of instrumental colour. The sound may be described as carnivalesque-blindingly colourful, almost gaudy in quality - but hiding just beneath its bright surface lurks a darker, ominous character.

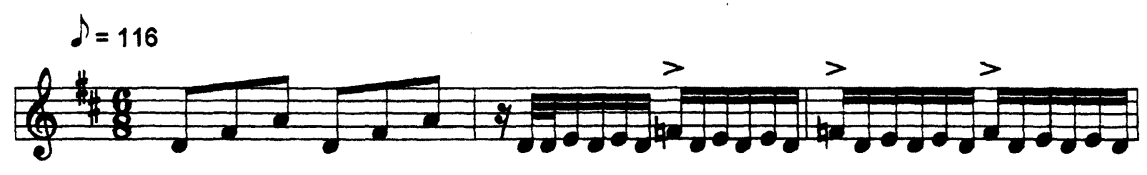

Example 1. "Opening Theme," Le Sang d'un poète

At the conclusion of the credits, the film presents us with a series of four intertitles in which Cocteau makes some ambiguous and puzzling comments on the nature of the poet and his/her work, as well as perhaps a challenge to the viewers of the film: "Every poem is a coat of arms. It must be deciphered." 15 This is underscored with a slowly descending motive for two flutes, lending the text a pastoral, classical quality, reinforced by the subsequent appearance of a masked Cocteau, draped with cloth in the manner of a Greek statue. The pastoral sound of the music momentarily suspends the distinctly modernist tone of the opening and thus serves to unbalance the spectator. Mood and character shift in ways that seem impossible to predict, allowing the film to sidestep any attempt to define it in terms of a conventional narrative. Through the vision of Cocteau, this prelude of sound and sight seem to suggest that the unfolding events are atemporal. Indeed, the fact that the events of the film happen during an "instant" of time framed by the collapse of the chimney shows that these events are outside of time.

In the first episode, entitled "The wounded hand, or the scars of a poet," the spectator is introduced to "the poet." Naked to the waist, he draws a face upon a canvas. Upon his back we see a scar in the shape of a five-pointed star, clearly identifying the young man as Cocteau himself. ${ }^{16}$ This first view of the poet is accompanied by what we can call the "star theme" (example 2). Like the

15 Jean Cocteau, Two Screenplays, 8.

16 The five-pointed star was a signature or symbol with which Cocteau frequently signed his work. Its use in this context is thought by most commentators to suggest an autobiographical link between the figure of the poet and Cocteau. 


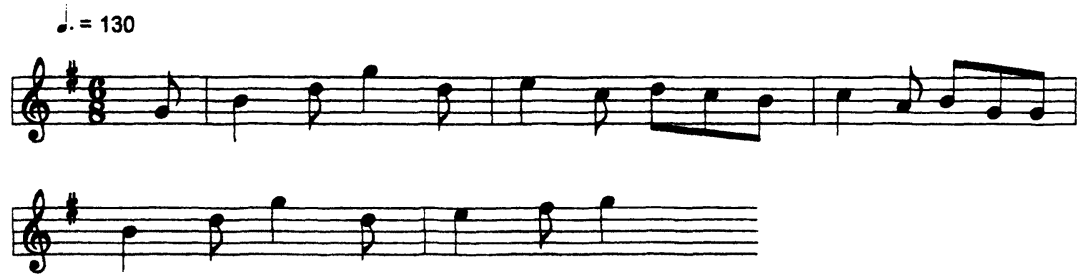

Example 2. "Star Theme," Le Sang d'un poète

opening cue, this theme is also in a quick $6 / 8$ time, but the tonality has shifted from $\mathrm{D}$ major to $\mathrm{G}$ major. It is heard during the close-up of the poet's scar, which suggests that the music, like the image of the five-pointed star, was selected by Cocteau as a musical signifier for himself. Marked by oddnumbered phrase lengths, the cue is frantic as it moves through a series of variations dominated by pitched percussion, woodblock, and piano. The piano presents the theme in open octaves in the high register, creating the sound of a music box or carousel. Once again the music invokes the air of carnival. The mouth of his artistic creation comes to life. Horrified, the poet tries to remove it, but in keeping with the carnivalesque notion of the grotesque, the living mouth imprints itself upon his hand. The entry of the poet's friend marks a change in the score, which now returns to the opening fanfare and theme. This superposition of music also creates a seeming contradiction with the visual component as the camera reveals the dismayed reaction of the friend who glimpses the unnatural mouth.

As the poet attempts to rid himself of the mouth, the music becomes portentous with an ascending theme in minor. Unable to rid himself of the phantom mouth, his rising panic is echoed by a doubling of the tempo and the introduction of an obsessive ostinato in the piano. The music retreats long enough for the dying hand to beg for air, but then reasserts itself as the poet surrenders to his conflicting passions and begins to make love to the ghostly mouth. The synchronization of music and image is so persuasive in this segment that it is impossible to take Cocteau's comments on the reordering at face value. Even after several viewings of the film, it is difficult to see where such a cue would have been more appropriate, in mood as well as in timing.

The furious nature of much of the first episode's music stands in sharp contrast to the musical accompaniment of Part Two: "Do the walls have ears?" The poet awakens to find that the door and windows of his room have vanished, replaced by a single mirror. A Grecian statue of a woman appears before him. He presses his hand to the woman's face, ridding himself of the mouth, which now gives voice to the statue. The score is mysterious, almost threatening in nature before it transforms into a rolling flute and saxophone duet that evokes a sense of the pastoral or the dream. The cue is much shorter than the scene it accompanies (that of the dialogue between the poet and the statue) and it is repeated three times. Each reiteration of the music is marked by an ominous chromatic trill for solo flute, the sounding of which seems to act as a point of synchronization with the visual. The trill is heard under the demand of the poet 
that the statue "open" the mirror for him, and concludes the cue as the poet steps on the chair in an attempt to enter the mirror. Assuming that there was no manipulation of the positioning of film and music, these points may be seen as what Cocteau describes as "synchronization by the grace of God." However, it is also interesting to note that within the scene, Cocteau plays with the synchronization of the diegetic sound to its corresponding image. As the poet taps on the mirror, the sound of his hand making contact with the glass is delayed by a second. This is a deliberate move on Cocteau's part, who describes the effect in the screenplay for Le Sang d'un poète: "He touches the mirror. His ring strikes it three times, but the sound is heard later than the contact."17 Clearly Cocteau was willing to manipulate synchronization for specific effect, further supporting the contention that he actively selected or manipulated the musical score beyond simple reorganization.

As the poet moves through the mirror (symbolically entering himself), the spectator is confronted with the concept of the transitional realm of the "zone." However, unlike the visions of later films, Cocteau and Auric chose to leave the transition unscored; indeed, the transition is completely silent-a world without sound, and perhaps even a world without life. The poet moves from the zone into the "Hôtel des Folies-Dramatiques," in which, as Arthur Evans suggested, he will confront elements from both his past and present. ${ }^{18}$ As he moves along the Hotel corridor, peering through the keyholes of several doors, the poet is accompanied by the "promenade" theme. Characterized by a slow dotted triplet, the B-flat minor theme accompanies the painful plodding of the poet as he moves from one displayed scene to the next. The theme-derived from the harmonic motion of minor i to major $\mathrm{V}$-acts like a dark cousin to Mussorgsky's Promenade from Pictures at an Exhibition, supporting and clarifying the recursive nature of the episode in which the poet becomes the voyeur, as he peers at scenes nested within the scene. Within this context, the music serves to delineate levels of identity, sounding when the viewer is positioned beyond the limits of the diegesis, watching the poet move from door to door, but fading to silence when the viewer is drawn into the diegetic level of the poet by Cocteau's use of a point-of-view shot. The spectator becomes the poet, looking through the keyhole.

The scenes within the four rooms are unscored, although diegetic sound is clearly heard: the sound of the gunshots as we witness the death and rebirth of a Mexican in the first room, the voices of Chinese opium smokers in the second room, and the bells of a flying child in the third room. ${ }^{19}$ Only the fourth room - the site of the "desperate meetings of the Hermaphrodite"20 - is scored with the sound of discreet snare rolls when the Hermaphrodite is revealed as a

17Cocteau, Two Screenplays, 21.

18Evans, Jean Cocteau and His Films of Orphic Identity, 92.

19It is important to note that in his screenplay for Le Sang d'un poète, Cocteau states that the second room is the site of the "flying lessons" while the third room is occupied by the opium smokers, an order reflected in several critical discussions of the film. However, all video copies of the film viewed for the purposes of the current work show that Cocteau reversed the order of these two rooms in the actual film.

20 Cocteau, Two Screenplays, 31. 
series of body parts. This has the effect of positioning the room as a place distinct in some way from the other three, an effect further supported by the camera position, which reveals the room not from the point-of-view of the poet (through the keyhole) but from a point within the room itself. The use of the snare suggests that this room is special, creating an air of ceremony in the "unveiling" of the Hermaphrodite. Indeed, this figure is the inner-self of the poet, both female and male together and yet never existing as either. When the Hermaphrodite reveals the sign reading "danger of death" (positioned over its genitalia), it is accompanied by a long snare drum roll that underlines the importance of the image-the most concrete articulation of Cocteau's axiom that in order to create the poet must first experience the death of the self. The Hermaphrodite is offering a warning to the poet that to face this inner self is to risk symbolic death, a death which the poet then undergoes through the first of his two "suicides." More importantly for our purpose, the use of the snare through this section is clearly deliberate in its accompaniment of the scene.

Angered by the seeming pointlessness of his own death, the poet quickly moves back down the hall. It is for this scene that Cocteau recorded the labored sound of his own breathing and heartbeat. In a letter from some time in 1930, Cocteau tells Auric of how he has "found a way of giving even more of [him]self" through the recording of his body. Cocteau states that listening to the film must be "painful" and that by making the film impossible to exploit it will become "sacred."21 In this written reference to the use and purpose of sound, Cocteau blurs the distinction between the synchronization of music, of diegetic sound, and of nondiegetic sound. Is this the sound of the poet's body? Is this the sound the poet hears? In the screenplay for the film, Cocteau writes that the poet's flight from the hotel is "accompanied by the double-sound of a fast beating heart and heavy breathing." 22 Without a clear reference, these sounds could be said to be functioning as nondiegetic music, supporting the mood of the moment with the addition of its own emphasis and content, and strictly synchronized to the length of the scene.

As the poet returns to his room, we see and hear the sequence, which perhaps poses the greatest challenge to the notion of random synchronization. His emergence from the mirror is accompanied by a cluster of vocal sounds, which quickly resolve to a brief passage of choral voice-leading in Baroque style. This is promptly replaced by a frantic trumpet that sounds a rapid rhythmic articulation of a dominant pitch over the slow unfolding of a descending minor scale. The trumpet mirrors the hatred etched in the face of the artist-a hatred he feels for the statue which has forced him to face his inner demons-as the downward motion in the accompaniment echoes the slow, pained steps he takes as he approaches the statue with the clear intent of murder. A fourth change in the musical texture accompanies the poet as he destroys the statue with a hammer. It is the sound of a brass fanfare which, like much of the film's music, is coloured with the sound of irony-in this case, irony designed to match

21 Caizergues, Correspondance: Georges Auric - Jean Cocteau, 120.

22Cocteau, Two Screenplays, 36. 
Cocteau's warning that those who smash statues (or attempt to overthrow the established order) risk becoming statues themselves. This warning is made manifest through the scene's final shot, the poet turned white with the dust of the shattered statue: he has transformed himself into a statue through his own violent actions. The high degree of synchronization between the various shots and events suggests that even if the music was not written specifically for this scene, it underwent a great deal of editing to create the final effect.

The third episode of the film also shows evidence of deliberate deployment of musical resources. "The Snowball Fight" is scored with what might best be described as a jazz-influenced funeral march, marked by a high degree of chromaticism. The frenzied action of the boys engaged in battle becomes a macabre dance when set against the slow unfolding of the musical accompaniment. The two seem almost irreconcilable, until one realizes that the music is a funeral march for the poet, whose statue, transformed from stone to snow, is being reduced to nothing but its pedestal by the schoolboys.

Like in the room of the Hermaphrodite, Cocteau uses a percussive roll to underscore a moment of particular importance. The figure of Dargelos holds aloft the snowball containing a piece of marble (the heart of the statue?), accompanied by a roll of the timpani. The young boy is struck and falls to the ground, dying. The timpani roll is now replaced by a restatement of the promenade theme, from Part Two. This is one of the few places in the film in which Cocteau reuses a cue, suggesting that there is a link between the death of the boy and the poet's journey through the Hôtel des Folies-Dramatiques. Like the tableaux of the hotel, the death of the boy is something that must be confronted by the poet if he is to flourish as an artist. The boy is both a literal representation of the poet (this scene is based on an incident from Cocteau's youth), as well as a figurative representation of childhood. Cocteau's decision to reuse the cue may be considered as a distinctly conventional way of suggesting a connection between disparate scenes within the film.

This notion is further developed in the film's final episode, "The Profanation of the Host." Like in the second episode, Cocteau creates a recursive structure here. The viewer watches both a presentation and its audience: the dead child from scene three lying at their feet, the statue-turned-woman and the poet play cards for a disinterested audience. ${ }^{23}$ The scene is introduced with a restatement of the "star" theme, recalling the link between the figure of the poet and Cocteau, which reasserts the notion that the presentation is in some sense autobiographical. The optimistic tone of the theme creates an air of irony, in its accompaniment of a card game played over the body of a dead child.

This music is also presented in a series of short excerpts deliberately positioned around views of the "actors" and the "audience" (among whom was the then famous stage transvestite "Barbette"). Musical accompaniment is avoided during the brief moments of dialogue, such as when the woman/statue tells the poet that without the ace of hearts he is "a lost man." When the poet

23 This poses an interesting question. At what level is the music thought to exist? Is it audible to the audience within the film? If so, when underscore is heard during shots of the loges, is this music functioning at a level doubly removed from the diegesis? 
retrieves the required card from the body of the dead boy (cheating by drawing on his childhood for artistic material), the supposedly shocked response of the "audience" is scored with a feverish arpeggiated passage for strings and harp. However, when the loges are shown in close-up, the spectators show little interest in what is transpiring below. The frenetic scoring is strangely at odds with the visual image. Cocteau offers a critique of the audience, which is more interested in social status and appearance than the art unfolding before them.

The scene is then interrupted by the appearance of an angel, who descends the stairs accompanied by nothing but the sound of a resonating wine glass. This marriage of sound and image cannot be mere happenstance. The single crystalline tone, a sound without beginning or end, produced by the circular motion of the hand, is a clear symbol of purity and clarity on any number of levels. It is the embodiment of the "angelic" made manifest in sound. As the angel "absorbs" the body of the boy, and then retrieves the ace of hearts from the poet's hand, a new musical motive is introduced. Slow and plaintive, the theme (derived from the major pentatonic scale) is heard on saxophone. It is the sound of nostalgia for a better past, a bittersweet reminiscence of the lost innocence of childhood. Once again, Cocteau undermines the feeling of both the music and the scene through a cut to the audience who seem entirely apathetic to the drama. The angel exits, accompanied once more by the translucent sound of the glass.

Even in this early film, long before either Auric or Cocteau had engaged in the production of standard narrative films such as Ruy Blas, it is possible to see levels of synchronization between the music and visual components of the film that call into question the veracity of Cocteau's claim of sonic spontaneity. Several cues are clearly edited in a careful manner so as to augment the visual image as strongly as possible. But what of Cocteau's other films? Like in the case of Le Sang d'un poète, the literature surrounding the production of these works accepts unchallenged Cocteau's accounts of the scoring process. Yet, we will reveal that a similar level of conscious organization was at work in these films, in the application of the musical score.

\section{La Belle et la Bête}

Writing in his journal on the day of the recording session for La Belle et la Bête, Cocteau states:

And now the silence, then the three white flashes which announce the image [visual timing cues for the conductor], then the image and the wonder of the synchronization, [which], since Auric avoids it at my request, ... must not occur save by the grace of God. ${ }^{24}$

Once again, Cocteau gives voice to his credo of film scoring, a claim which is maintained even in the liner notes for a recent recording of the score which state that Auric's work is "unsynchronized" with the film. ${ }^{25}$ It is even suggested

24Rorem, "Cocteau and Music," 168-69.

25Liner notes to Georges Auric, La Belle et la Bête (Complete Film Score, 1946), Axios Chorus, Moscow Symphony Orchestra, cond. by Adriano (Marco Polo, 8.223765, 1996). 
that Auric completed the score before viewing the film. ${ }^{26}$ However, in Cocteau's 1951 conversation about La Belle et la Bête with André Fraigneau, he states that "Auric wrote his score to match the images, which made it almost impossible for me to break a single rhythm without being discourteous to the composer." 27 According to Fraigneau, Cocteau requested very few edits, and only occasionally was the final level of the music adjusted in any noticeable way in the interest of dialogue. This account clearly suggests that Auric had seen rough cuts of the film, at the very least. Far from unsynchronized, the film score shows a high level of integration with the visual narrative, which can create and support meaningful interpretations on both large and small scales.

Auric's score calls for a conventional orchestra with piano, wordless chorus and an expanded percussion section. There is a great deal of music in the film: almost two-thirds of the film's 96 minutes are accompanied by music. It is important to note, however, that within scoring conventions of the time, such lengthy scores were commonplace in both Europe and Hollywood.

The overall structure of the score is quite simple. Music is confined to the realm of the Beast; only Belle is accompanied by music beyond the walls of his castle and the surrounding forest. In keeping with Cocteau's philosophical view, we may suggest that the realm of the Beast represents the poetic. It is a world apart from our own, surrounded by a thick forest, the zone, through which one must pass in order to gain the insight of the artist. As such, it is a mythic place, personified by the almost constant musical accompaniment. Belle, whose fate lies within the walls of this impenetrable zone, is an extension of the poetic into the real world. She is perfect beauty of both body and spirit made manifest in the drab sphere of the real. This connection to a higher plane of poetic existence defines Belle as one whose natural state is also accompanied by music. As we will see, musical associations with characters other than the Beast are made only through her presence.

Auric's musical style is a combination of Hollywood romanticism and French impressionism. The opening cue is very much in the classical Hollywood tradition of an overture with the statement of several contrasting themes that move through a series of key and textural changes, somewhat in the manner of a pastiche. This contrasts strongly with many of the cues composed for scenes within the Beast's castle. Characterized by ostinatos, parallel fourths and fifths and the timbre of the wordless choir, these cues create an orientalized, other-worldly sound similar to that of Ravel's Daphnis et Chloé. In particular, the voices create an atmosphere of mystery and wonder. Bearing a striking similarity to Dimitri Tiompkin's score for Lost Horizon (1937) and Herbert Stothart's original score for The Wizard of $\mathrm{Oz}$ (1939), both of which engaged wordless choirs to evoke the magic of Shangri-la and Oz respectively, this technique has become a staple of film scoring conventions.

As in many of his other works, Auric employs a series of themes and motives in the development of the score; however, he does not use them in the leitmotif

26 American Cinematographer Online Magazine (September 1997), http://www.cinematographer.com/magazine/sep97index.htm.

27Fraigneau, Cocteau on the Film, 73 (our emphasis). 
style which was by this time well established in the Hollywood tradition. Auric uses his themes as building blocks to create a sense of continuity in what is, by its very nature, a discontinuous medium. His musical material creates associations of atmosphere and mood, moving from the playful and magical, to the dark and mysterious, to the horrific. His motives are not simply used to evoke particular characters, but to project that character's emotions, and states of mind-most importantly, the love that develops within Belle for the Beast. Much of the score is derived from two themes (examples 3 and 4).

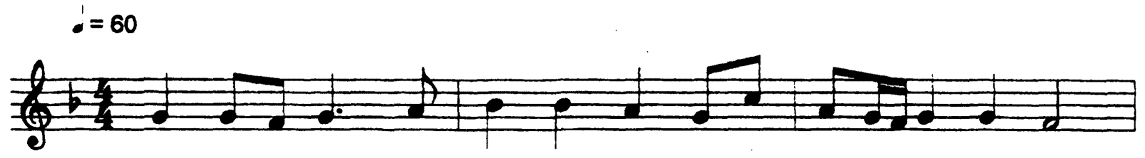

Example 3. "Belle's Theme," La Belle et la Bête

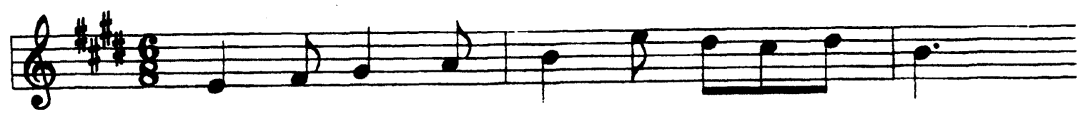

Example 4. "Beast's Theme," La Belle et la Bête

The first is most often associated with Belle's feelings of love for the various characters (the Beast; her father, the merchant; her brother, Ludovic; and her suitor, Avenant), while the second is most often heard in connection with the Beast's love of Belle-it is first heard as he asks for her hand in marriage. Both themes are deceptively simple in construction: diatonic, characterized by arch-like construction, with a concentration of rhythmic motion at the end of the phrase. However, the simplicity of the material allows Auric to use the themes in an astounding variety of ways. The first measure of one theme or the other is audible in almost every musical cue.

Following the opening titles, there is little music during the first few scenes, all of which take place in the "real" world. The first cue accompanies the dialogue between Avenant and Belle, in which she refuses his increasingly forceful advances. Derived from Belle's theme, this cue establishes Belle as a character distinct from her tyrannical sisters (she is privileged by musical accompaniment) and serves the pragmatic purpose of accompanying the first view the spectators have of the film's stars Jean Marais (Avenant/The Beast) and Josette Day (Belle). It is not until the Merchant begins his journey home from the port, where he learns that a shipwreck has left his family destitute, that music becomes an important (almost equal) component of the narrative. As the Merchant loses his way in the forest, his growing panic is paralleled in both the musical storm which accompanies him, and the literal storm which drives him further into the woods until he reaches the castle of the Beast. Swirling, portamento strings echo the rising wind as short stabs in the brass mimic the flashes of lightening. The Merchant enters the castle grounds to the 
sounds of a grand fanfare that dies away to the level of the storm, now kept at bay by the Beast's magic. The theme of the fanfare is derived from the Beast's theme in a slow triplet rhythm. The entrance of the fanfare is exactly timed to synchronize with the appearance of the Beast's castle, suggesting that Auric composed his music to match the timings of the scene's significant events.

When the Merchant takes refuge in the castle, he finds himself within a grand hall. At the center of the hall, before a blazing fire, sits the Beast's table, upon which is laid a sumptuous meal. The luxury and plenty of the great hall stand in stark contrast to the overgrown and neglected exterior. Auric matches this change in scene with an equally striking change in musical texture, introducing various impressionist traits, including the wordless choir. The choir has the effect of changing the filmic space in a profound way. No longer in the real world, the Merchant finds himself in a hall inhabited by living candelabras and statues. The voices in the soundtrack provide a disembodied presence to the film, furthering the impression that the Beast's castle is a living entity. Like a Greek chorus, the voices are spectators to the drama, bridging the gap between the diegetic and nondiegetic realms, simultaneously adding to the sense of the fantastic, while drawing the spectator deeper into the narrative.

The following morning, while searching for his horse, the Merchant sees a wondrous rose growing in a hedge. As he picks the rose for his daughter Belle, a great wind blows him to the ground and he looks up horrified to see the Beast towering over him. The Beast informs the merchant that of everything in his castle he loves the rose most of all: the penalty for picking the rose is death. The merchant pleads for his life and the Beast grants him three days either to return and face his doom or to send one of his daughters in his stead. The accompaniment for the scene builds gradually from a slow, furtive $\mathrm{C}$ minor to a dramatic orchestral tutti on the dominant G. Like the use of the wordless voices, this approach is an early example of a now-established film scoring convention, which builds the tension with an unresolved dominant while the actual event that precipitates the tension (in this case, the appearance of the Beast) is unscored. ${ }^{28}$ The use of this technique requires a high level of synchronization between the music and visual depiction of the narrative. The cue builds during the first few measures in $\mathrm{C}$ minor up to a dramatic fanfare in $\mathrm{C}$ major as the Merchant sees the ruined splendor of the Beast's castle grounds in daylight for the first time. As he searches the empty stable, and then finds the body of a slain deer, there is a related change in texture as the mood changes from that of wonder to terror. Finally, the arrival of the tutti G-minor coincides with the Merchant's sighting of the rose. Once again, with such a high level of emotional and temporal synchronization, it would be hard to argue that Auric was deliberately attempting to avoid matching his music to Cocteau's film.

After she learns of her father's adventures, Belle slips from her house, determined to take his place in the Beast's lair. Her escape is accompanied by the sound of tremolo diminished sevenths in the upper stings, slowly rising as

28See for example, the climactic final scenes of Star Wars (1977-score by John Williams) or Aliens (1986-score by James Horner). 
she and the Beast's magic horse creep from the stable. She gallops from the house to a dramatic variation of the Beast's theme; here, Auric clearly informs the spectators of what is to come. The score returns to the romantic quality of the Merchant's passage through the forest. This again makes a marked contrast with the cue which accompanies Belle as she explores the Beast's castle for the first time. Both of the two main themes are clearly heard in a variety of settings accompanied by highly chromatic material reminiscent of Debussy. While the musical materials do not correspond directly with actions of a specific scene, Auric employs various keys and textures that change as Belle moves through the various rooms, including the now famous scene of Josette Day floating down a corridor surrounded by billowing, diaphanous curtains. The cue shows no trace of fear, only wonder, as Belle is magically guided to her room. However, the effect of the whispering furniture combined with the sight of the bed turning itself down (a powerfully sexual and menacing sight) causes Belle to lose her nerve and she flees from the castle. Panic turns to terror and Belle faints from the shocking visage of her captor, when she is confronted by the Beast for the first time. Auric's score reflects this rising sense of alarm, maintaining the tension as the Beast carries the now prostrate Belle back to her room, placing her upon the bed. This air of danger is maintained as the Beast lowers his face to Belle's, his eyes ablaze with some unnamed passion. As he draws closer, the music builds to an unbearable tension with both chorus and orchestra articulating denser and denser clouds of sound. Only when Belle awakes, and the Beast recoils from her gaze, is the tension broken, and the cue brought to a close.

In the following scene, we learn of the noble character of the Beast: that he is a monster in appearance only. When he asks Belle if she will marry him, we hear an almost childlike articulation of his theme, quickly followed by a disjointed statement of Belle's theme as she rejects his request. The Beast's theme is heard again, now chromatically altered as the pained expression registers on his face. Auric again is "playing" the psychological drama of the narrative. The Beast's theme, like his love for Belle, is complete, yet it sounds like the naïve, innocent love of a child. Belle, however, is unable to return this love: her theme is fragmented and uncertain of itself. Throughout the rest of the film, Auric will use the development of Belle's theme to mirror her growing love for the Beast, such as the scene in which the Beast offers Belle a gift of a pearl broach. She accepts it grudgingly, and offers little in the way of kindness to her captor; however, when the Beast has left her room, the mood changes. Her countenance softens as she holds the broach and in the soundtrack we hear a larger fragment of her theme.

When the Beast allows Belle to visit her family, she tells them of the wonders and riches of her captor's castle. At the urging of Belle's sisters, Avenant and Ludovic plan to rob the Beast. Belle learns of the plot and returns to the castle to find the Beast close to death. Auric weaves the two themes together, as the visual narrative cross-cuts between the robbery and Belle's confession of her love. Avenant is slain by a statue of the goddess Diana who guards the Beast's treasure house. At the moment of death, he is transformed into the likeness of the Beast, while the Beast's appearance is changed into that of Avenant. One last time, Auric returns to the sound of the chorus, the voices of the castle dying 
with the transformation of the Beast. Reunited once more, Belle and her prince are magically carried away to his distant kingdom, accompanied by the Beast's theme, now heard as a triumphant march.

Cocteau's La Belle et la Bête goes far beyond the conventional telling of a fairy tale through his linking of the classic story with his own approach to notions of the "poetic." Auric's music serves this vision well by offering a subtle parallel to the visual narrative through his interpretation of the emotional journey of the film's protagonists. Furthermore, his music was composed to match not only Cocteau's general poetic intent, but to synchronize with dramatic and technical configurations of numerous specific scenes.

\section{Orphée}

The brief period between the release of La Belle et la Bête (1946) and Orphée (1949) was the most prolific for Cocteau and Auric's film collaborations-it was a period that brought forth Ruy Blas (1947), L'Aigle à deux têtes (1947), and Les Parents terribles (1948). By this point, Auric was also working with a number of other directors, such as Terence Young and Charles Crichton-he had become a skilled and respected composer of film music. Nevertheless, according to Cocteau, the renewed collaboration was to return to the methods first employed in Le Sang d'un poète, in which Cocteau supposedly reordered cues composed by Auric without any knowledge of the finished film: "[W]ith Orphée I picked up, after twenty years' interval, ${ }^{29}$ the thread of Le Sang d'un poète in which I had played the same theme with one finger as it were (I know I'm repeating myself but I can't help that), I took the most irreverent liberties with the composer." 30

Indeed, most commentators accept at face value this report which suggests that, as Cocteau claimed with Le Sang d'un poète, Auric composed his music before actually seeing the film. The manuscript reconstructed for a 1999 recording of a "suite" from Orphée reveals that as much as one third of the music that Auric composed for the film was left off the finished print as a result of Cocteau's editorial decisions. It involved fading out or cutting off cues prematurely (in terms of musical construction) or leaving the music out altogether, which clearly supports the notion that Cocteau took great liberties with the music. ${ }^{31}$ However, once again we will argue that a closer reading of some of the cues indicates that Auric was far more aware of the content of the film than Cocteau has suggested.

Again, Auric constructs his score with a small collection of themes which come to represent general states of being as opposed to a specific character or object. The two most important themes are presented in examples 5 and 6.

29It is interesting to note that in this quote Cocteau seems to suggest that the thread was not followed for La Belle et la Bête, although this clearly contradicts some of his earlier (and later) pronouncements.

30Fraigneau, Cocteau on the Film, 75.

31 Liner notes from The Classic Film Music of Georges Auric 2: Orphée, Ruy Blas, Thomas l'imposteur (Suites), Slovak Radio Symphony Orchestra (Bratislava), cond. by Adriano (Marco Polo $8.225066,1998)$, vol. $2,8$. 

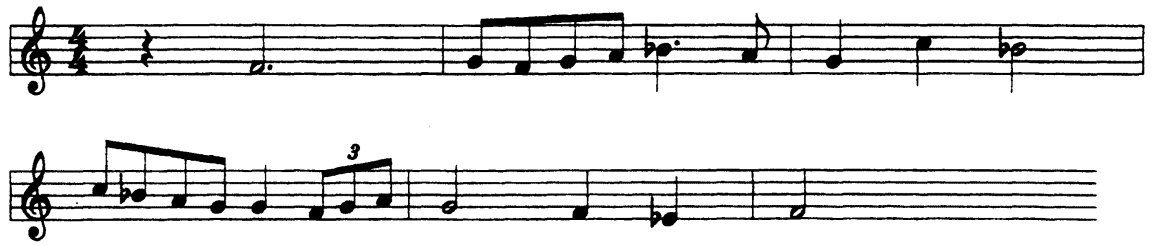

Example 5. "Orpheus in Transition," Orphée
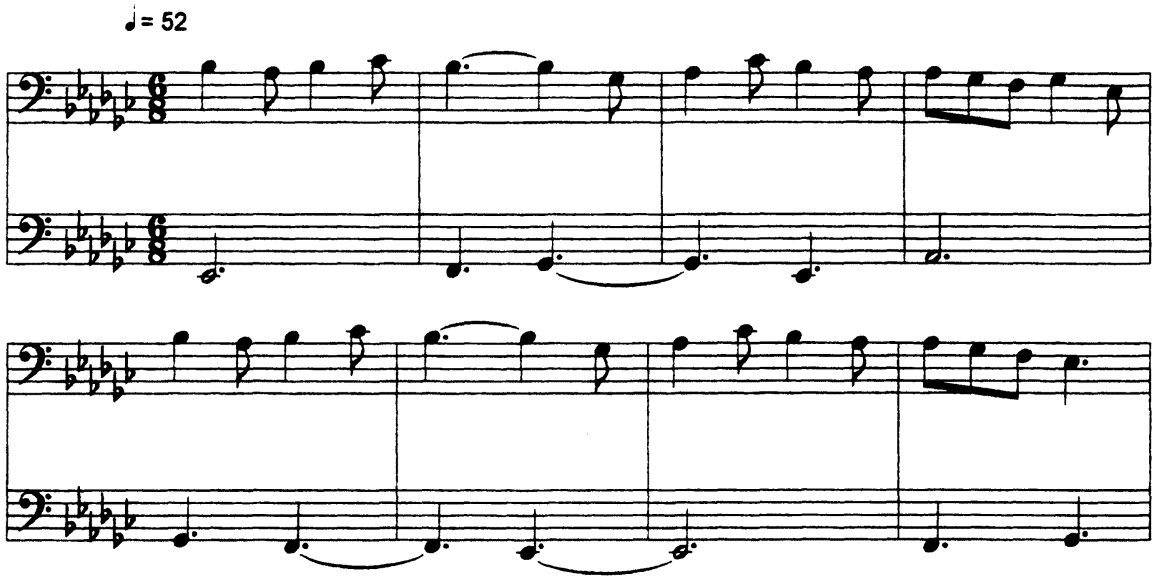

Example 6. "The Zone," Orphée

Before discussing the role of music in the film, it is important to draw attention to the similarity between example 5 , which we have labeled as "Orpheus in Transition," and example 3, "Belle's Theme" from La Belle et la Bête. With the exception of the opening $\mathrm{F}$ in example 5, the two themes present identical melodic contours for eight consecutive notes. Maestro Adriano, conductor for the recording of the Orphée suite, remarks that similar themes may also be found in scores for the Auric/Cocteau collaborations of Les Parents terribles and Ruy Blas. The subject matter in the four films would seem to have little in common; however, all four starred Jean Marais in a leading role and Adriano suggests that the theme may be Auric's musical tribute to the friendship that existed between the younger actor and director who made him famous. Developing this theory even further, he states that it is possible for the listener to distinguish the friendship of the "masculine and feminine (or even 'homo-' or 'heterosexual') [in the] ascending or descending five-note cells, placed in accordance with the open (or hidden) message of the particular sequence of the film." 32 Unfortunately, the conductor/writer fails to clarify how these notions of gender and sexuality are encoded within the music, and it is hard to hear them as such. Instead, we would suggest that the theme is Auric's 
musical analogy to Cocteau's notion of the "poetic" film, which values subjective interpretation over objective reality. The theme is not a mimetic representation of this subjectivity but a musically consistent cell serving to remind the audience at a subconscious level (if not a conscious one) that the film is a creation of the imagination of Cocteau.

Set in post-war France, the story is loosely based on the myth of the same name; however, rather than as a musician, Cocteau casts his title character as an aging poet who has lost the spark of creativity. The plot is further complicated by the characters of the Princess (the manifestation of death on Earth), and Heurtebise, her servant/chauffeur. While carrying out her grim duty, the princess falls in love with Orpheus. Against the orders of her mysterious superiors, she enacts a plan to help Orpheus regain his creativity, a plan which risks destroying them both.

The narrative progression of Orphée is defined by the gradual movement of the protagonist from the world of the living, through the zone, to that of death, and then by his return to the world of the living. These progressions are symbolic of Cocteau's belief that the poet must die in order to be reborn. However, rather than scoring what we might define as the initial and final states of this transfiguration, Auric (or Cocteau) has instead elected to score the moments of "passage" from one condition to another; it is as if the importance is placed not on the destination but on the journey. Even more specifically, music is used to support the transitional moments of Orpheus alone. Other key points in the film are enacted without the benefit of musical accompaniment such as: the death and "rebirth" of Cegestius, another of the Princess's servants; the death and rebirth of Orpheus' wife, Eurydice; the supernatural comings and goings of the Princess and Heurtebise; and the tribunal held on the far side of the zone-a court which eventually decides the fate of the various characters. Only Orpheus, as he moves deeper and deeper into the zone both metaphorically and literally, is lent the support of music.

This is the rationale behind the label given to example 5: "Orpheus in Transition." The theme is characterized by stepwise motion, with the only exception being an upward leap of a perfect fourth. The tonality is that of $F$ Mixolydian, which is not fully revealed until the penultimate measure, when the E-flat is articulated in a phrase-ending distinctly reminiscent of Gregorian chant. Indeed, the theme is the first clearly diegetic music heard in the film, as Orpheus escapes through his bedroom window after telling his wife that he wishes to sleep. Instead, he returns to the Princess's car where he may hear the "poetic" radio broadcasts: poems transmitted by Cegestius acting on the orders of the Princess. This act of deception on the part of Orpheus marks his first conscious step in the journey that will result in his death and rebirth. By taking this unconventional way out of his "real" life (using the window to exit his room), Orpheus is preparing himself for his eventual journey through the mirror, another portal made of glass. The "Orpheus in Transition" theme is also heard as Orpheus and Heurtebise emerge from their second journey through the zone into the realm of death, to reclaim the lost Eurydice. This is another key point in the transformation of Orpheus into the true poet. In both scenes, the theme is heard twice over a tonic pedal with the repeat harmonized in 
parallel fourths, further evoking the atmosphere of chant. An obvious and deliberate gesture on the part of Auric, this evocation lends the various scenes an air of great age, perhaps even creating a sense of timelessness. For Cocteau, this is a journey that must be made by the artist if he is to understand the "poetic" aspect of existence, and, by extension, to understand the purpose of life itself. As such, it is a sacred journey which requires the utmost commitment on the part of the artist and her/his audience. The atmosphere of chant in this theme also contributes to an atmosphere of the sacred.

The theme outlined in example 6 is also clearly constructed in the mold of Gregorian chant. It appears that Auric constructed this theme and its bass accompaniment in a manner similar to that of the eleventh- and twelfth-century practice of the "rhythmic modes." The upper voice is clearly articulated in a repeating pattern of quarter-note and eighth-note with some variation; however, an examination of the lower voice reveals that it too is based on this repetition of long and short rhythmic values. Rather than quarter-notes and eighth-notes, the pattern employs dotted half-notes and dotted quarter-notes. As such, the pattern is the same but moves at one-third the rhythmic value. Harmonically, the line stresses the open compound fifth, as in the case of the parallel motion in example 5, a convention of film scoring which (dependent on the narrative context) may be designed to evoke an air of timeless spirituality. Such is certainly the case in the accompaniment for the journey of Orpheus and Heurtebise through the zone. Filmed in the ruins of Saint-Cyr, a monastery destroyed during the Second World War, the two traverse a wasteland of high stone walls, open to the sky above, surrounded by piles of rubble. Shot at night, the walls are thrown into sharp relief through the use of high intensity lights, further emphasizing the wreck and ruin of the location. The scene has an air of great age and neglect, supported by the sound of music which bridges the conventional setting of modern-day France with the ancient. Again, it is difficult to see where else in the film such a cue would have resided.

If Cocteau reordered the cues, we must ask for what was this passage originally intended? It is possible to suggest that Auric wrote the cue for this particular scene without viewing it beforehand. However, the timing of the cue and the scene are exactly the same (2:52), and the complete cue reconstructed for the soundtrack recording has a timing of 2:50, suggesting that nothing was cut or added to the cue before it was inserted into the film. Furthermore, there is a moment of indisputable synchronization which occurs in the final seconds of the cue. As Orpheus and Heurtebise emerge from a doorway and begin the descent of a stone stairway, the music begins a chromatic descent, imitating the physical gesture in what may only be described as "Mickey Mousing." 33 This level of synchronization between musical and physical gesture over two minutes into the cue clearly supports one of two possible conclusions: Auric

33 "Mickey Mousing" is a term used by film score practitioners to describe the literal linking of musical gesture with the physical gesture seen on screen, for example scoring a character falling down a staircase with a downward glissando punctuated with a staccato articulation as the character reaches the bottom of the stairs. The source of the name is derived from the regular use of this technique in the accompaniment of cartoons. See Fred Karlin, Listening To Movies: The Film Lover's Guide to Film Music (New York: Schirmer, 1994), 79. 
knew the length and content of the intended scene, indicating that even if he had not viewed the scene, it was already completed when he wrote the music; or Cocteau recut the scene to fit Auric's cue. Either way, one is compelled to conclude that conscious effort was made to synchronize the musical and visual components of the scene.

A similar argument may be made for the cue which accompanies Orpheus as he chases the Princess through the streets of the city. A frantic cue in a meter based on five, the music twirls about the protagonists as Orpheus seems on the verge of cornering his prey, time after time, only to find she has mysteriously vanished. Within the film, the cue is $2: 34$ in length. The recent reconstruction of the score reveals that Cocteau fades the cue in after six seconds (the fade-in is clearly audible on the film's soundtrack), bringing the total length of the original cue to approximately $2: 40$. In his discussion of the film's music, Cocteau states that he "put the scherzo he had composed for the comic home-coming into the chase through the deserted house." 34 Two points of clarification are necessary here. First, the only cue that even comes close to the nature of a scherzo is the one that accompanies the chase through the city, so there can be no doubt as to which cue Cocteau is referring; second, the only "chase" in the film is the one which occurs in this same scene. Consider the scene for which Cocteau states the music was originally intended. The total length of the scene (Orpheus: "Comment, six heures!" to Orpheus: "Dans ma chambre") is four minutes and three seconds, clearly much longer than the corresponding cue. Even if we consider only part of this scene as a possible original location of the cue (from the time Orpheus retrieves the threatening letter to his exit upstairs), it is still over three minutes in length, with much of the scene occupied by discussions of the contents of the letter. It is difficult to accept that Auric, by this time an experienced film composer, would have produced something so aggressive, for a scene in which dialogue is so important. When one compares this awkward association of visual and music with the level of synchronization within the chase scene (which matches the cue's timing almost to the second, and contains virtually no dialogue, which further creates a privileged space for more aggressive music), it is difficult to accept Cocteau's claim about the cue's original intent.

In addition to the original music of Auric, the film also includes "Eurydice's Lament" from Gluck's Orphée et Euridice (1762). It is interesting to note that this is the one piece of music not associated with the character of Orpheus, even though it is first heard (albeit briefly) when the Princess switches on a radio in her room. Orpheus is furious and demands that the station be changed (indicating his guilt at being in the room of another woman?). However, the cue is then heard only during moments of tenderness between Eurydice and Heurtebise, coming to signify that as the Princess has fallen in love with Orpheus, so to has Heurtebise fallen in love with Eurydice. This cue also seems to float between the clearly diegetic and nondiegetic. No radio is seen during the first encounter between Eurydice and Heurtebise, yet one has the sense that the

34Caizergues, Correspondance: Georges Auric-Jean Cocteau, 75. 
music is audible to both characters, especially since it has already been heard in a clearly diegetic setting earlier in the film. Cocteau comments on the use of this cue:

I recorded Eurydice's Lament by Gluck, meaning to use it only for the wireless in the cottage. But when I cut into Auric's music at the first shot of Heurtebise's entrance, I noticed that the first and the last note of Gluck's music fitted exactly with the first and last images of the scene, and I shamelessly took advantage of that little miracle. Miracles of that kind are fairly common with people who calculate only by instinct. ${ }^{35}$

It is unlikely, although not inconceivable, that both the cue and the scene last for three minutes and thirty seconds. However, several factors require some careful consideration. As Cocteau states, he originally intended the cue to be used only in the cottage, a scene of less than forty-five seconds. This would not be of importance if not for the fact that the version of "Eurydice's Lament" employed in the film was orchestrated and recorded by Auric who produced a passage lasting exactly the length of the Eurydice/Heurtebise scene. If the original intention was to use only forty-five seconds of the work, why did Auric produce a cue almost five times the required length-exactly the length required for the second scene? It would seem more reasonable to suggest that Cocteau and Auric had every intention of using the passage in both scenes.

The evidence is compelling. Jean Cocteau seems to have deliberately misled commentators and critics with his comments on how he used musical accompaniment with his narrative films. Furthermore, Cocteau has been assisted by those interpreters who have sought to establish a dichotomy between the modernist, avant-garde vision of film and what they have regarded as the crass commercialization of Hollywood. Yet the question remains, what are some possible reasons for his claims. The hostile reception he received at the hands of the French surrealists and the mainstream of French literary society of the 1920s and 1930s contributed to Cocteau's vision of himself as an artist outside of traditional ideologies or literary schools. He saw his work as a unique and personal vision of the poetic. He was constantly searching for aspects of this vision that could be found nowhere else. Such an aspect could be his claim to the non-synchronization of his film scores. It positioned him and his creations outside the accepted conventions of narrative film, while centering him as the dominant creative force in the production of the work.

Cocteau was capable of direct involvement in every facet of his work save music. He could write scripts, design sets and costumes, select camera angles, as well as edit and reassemble the produced footage. He produced sculptures and paintings for his films, as well as illustrating the opening titles by hand on occasion. In his final film, Le Testament d'Orphée, he moved from behind the camera to in front of it, performing the title role himself. The one aspect of his films over which he was forced to relinquish control was music. This is particularly noteworthy due to Cocteau's self-appointed role as a spokesman 
for the Parisian musical avant-garde in the decade following the First World War, and the sheer number of musical metaphors Cocteau employs in the discussion of his films. ${ }^{36}$ In light of all this, could we posit that Cocteau exercised more conventional musical control over his film scores than traditionally thought? The talent and skill of Cocteau the poet are beyond question, however, the work of Cocteau the "composer" must be reevaluated if we are to understand the relationship between music and film in the works of this legendary artist.

\section{Abstract}

Jean Cocteau's relationship with music has never been explored in detail with regard to his films. Given his well-known statements against synchronization, Cocteau appears upon first glance not to have paid much attention to the relationship between image, word and music, entrusting the music to his long-term friend Georges Auric. However, a closer examination of Auric's scores in the context of their films reveals a much closer corraboration of music and film than previously thought by specialists (or admitted by Cocteau). Analysis of musical and filmic elements in Le Sang d'un poète (1932), La Belle et la Bête (1946) and Orphée (1949) presents a complex and rich yet traditional approach to film scoring both by Auric and Cocteau.

\section{Résumé}

La place qu'occupe la musique dans les films de Jean Cocteau n'a jamais fait l'objet d'une étude approfondie. En effet, le parti pris ouvert de Cocteau contre la synchronisation fait penser qu'il accordait peu d'importance aux liens entre l'image, la parole et la musique, d'autant plus qu'il confiait celle-ci à son fidèle ami Georges Auric. Toutefois, un examen attentif des partitions d'Auric en regard des films correspondants permet de révéler qu'il existe, entre musique et film, une relation beaucoup plus étroite que ce que les spécialistes avaient cru jusqu'ici (ou que Cocteau admettait). Une analyse des éléments musicaux et filmiques des productions Le Sang d'un poète (1932), La Belle et la Bête (1946) et Orphée (1949) suggère une approche riche et complexe, quoique conventionnelle, de la composition de musique de film, à la fois par Auric et Cocteau.

36 See for example the earlier noted comment in which he describes his supposed approach to music, stating that he is playing "the same theme with one finger, as it were." Ibid., 75. 